\title{
Product innovation as a key success factor to build sustainable brand equity
}

\author{
Jalal Hanaysha ${ }^{\mathrm{a}^{*}}$ and Haim Hilman
}

${ }^{a}$ College of Business, Universiti Utara Malaysia, 06010, Sintok, Kedah, Malaysia ${ }^{b}$ College of Business, Universiti Utara Malaysia, Malaysia

\section{H R O N I C L E}

Article history:

Received January 20, 2015

Received in revised format 16

February 2015

Accepted 20 April 2015

Available online

April 222015

Keywords:

Brand equity

Product innovation

Automotive sector

\begin{abstract}
A B S T R A C T
In highly competitive markets, building brand equity has become one of the first priorities for many organizations as it brings several benefits and reputation for them. Past researches have acknowledged that consumers look for brands which provide them with differential values through innovative product and service features. However, despite the importance of product innovation in determining an organization's success, very limited studies have intended to examine its effect on brand equity. In the present study, we aim to examine the effect of product innovation on brand equity in Malaysian automotive market. The data were collected from 287 passenger cars owners through self-administered questionnaire at several shopping malls in northern Malaysia. The findings revealed that product innovation had significant positive effect on overall brand equity and its dimensions namely; brand awareness, brand loyalty, brand image, and brand leadership. Based on the results of this study, several implications are discussed to enlighten our knowledge on important innovation activities that could develop favorable brand equity. Finally, limitations and future research suggestions are highlighted to gain better insights on brand equity development.
\end{abstract}

C 2015 Growing Science Ltd. All rights reserved.

\section{Introduction}

Brand equity has gained a significant attention from a number of scholars in past literature, because it is the main source for competitive advantage (Zou \& Fu, 2011). It was defined by Aaker (1991, p.15) as "a set of brand assets and liabilities linked to a brand, its name and symbol that add to or subtract from the value provided by a product or service to a firm and/or to that firms' customers". The advantages of obtaining strong brand equity include easier brand extension, ability to charge price premium on products and services, higher customer demand, and low risk from competition (Yang et al., 2015). Nowadays, several organizations are aware that brand equity is one of their most important assets in promoting their products and services. It preserves an organization's value and increases the loyalty of customers (Pouromid \& Iranzadeh, 2012). Thus, the higher perceptions of positive brand equity in customers' minds lead to higher revenues and better performance.

\footnotetext{
* Corresponding author.

E-mail address: jalal.hanayshi@yahoo.com (J. Hanaysha) 
Extant literature indicates that organizations can employ several strategies to enhance and manage their brands effectively. One of the important tangible approaches is product innovation strategy (Ponnam \& Balaji, 2015; Tu \& Hwang, 2013). This approach includes making continuous and significant improvements to the current products and creating new one with attractive features (Ponnam \& Balaji, 2015). Previous researches realized the significance of product innovation strategy as radical modifications to products in improving the perceptions of customer toward product quality, and this may also affect brand choice and purchase decision (Fauji \& Utami, 2013; Han et al., 2001). However, despite the importance of product innovation in affecting brand choice, empirical research on the direct link between product innovation and brand equity is limited. Therefore, this study aims to examine the direct link between both variables.

To explore our knowledge about the direct effect of product innovation on brand equity, this study is focused on automotive industry in Malaysian market. This is because most of the previous studies on this topic were conducted in western countries and only few intended to test the variables in Asian context. Moreover, the automotive industry in Malaysia represents one of the main industries under manufacturing sector that make significant contribution to economic development. The following sections start by literature review on variables followed by methodology and analyses of results. Then discussion and conclusion are presented with some notes on the practical implications based on the results of hypotheses. Finally, limitations and future research directions are highlighted.

\section{Literature Review}

\subsection{Brand Equity}

Brand equity is one of the main topics that has established its toots in marketing literature and provides significant implications for effective brand management with regard to various brands (Aaker \& Keller, 1990; Keller, 1993). Several definitions of brand equity were reported in the literature. For instance, it was defined by Aaker (1991) as the positive or negative influences toward the preferences and buying decisions of products or services marketed under a brand. Similarly, Farquhar (1989) described brand equity as the intangible assets associated with a brand based on the perceptions of customer. Hanaysha et al. (2013) also defined brand equity as the intangible values linked to a certain company through its brand name. Ailawadi et al. (2003, p. 1) thought about brand equity as the "outcomes that accrue to a product with its brand name compared with those that would accrue if the same product did not have the brand name”.

Acquiring high or positive brand equity provides organizations with several advantages. In particular, positive brand equity contributes to better customer satisfaction, improved brand loyalty, and higher levels of confidence to charge price premium after developing trust among customers (Aaker, 1991, Park \& Srinivasan, 1994). Furthermore, firms with high brand equity can benefit from easier line extensions in new markets and position themselves successfully in the mind of customers (Broniarczyk \& Alba, 1994; Mela et al., 1997). It also leads to increased sales, profit margins, and stock-market value (Gupta et al., 2004). Lieven et al. (2014) indicated that organizations with positive brand equity spend less on promotional expenses and become less subject to the threats of competition.

Previous literature indicated that brand equity can be measured in terms of several dimensions. Aaker (1991) proposed four dimensions to test brand equity and this includes perceived quality, brand awareness, brand loyalty, brand association, and other propriety assets. On the other hand, Keller (1993) considered brand awareness and brand image as the main elements in the formation of brand equity. He referred brand awareness to the ability of customers to identify a brand and the likelihood that such brand would be considered in future purchasing of a certain product or service. Brand image is reflected through brand meaning or impressions expressed in the memories of customers. Similarly, Lassar et al. 
(1995) suggested five dimensions to measure brand equity and this includes performance, trustworthiness, social image, value, and attachment. Later, Aaker (1996) added brand leadership and market share as important components of brand equity. However, this study focuses on four dimensions to measure brand equity namely brand awareness, brand image, brand leadership, and brand loyalty. Only few studies contributed to brand leadership as one of the measurements of brand equity. Therefore, this study is planned to provide theoretical contribution to brand equity theory through its measurements using the four dimensions stated above.

Brand awareness can be expressed according to the potential ability of customers to recognize and remember a brand when they have to purchase a certain product or service (Aker, 1991). On the other hand, brand loyalty is reflected through customer's repurchase behaviour without having any intention to switch to other competitors even at different range of prices (Buil et al., 2008). Brand image was also defined in previous literature as the thoughts attached in the memories of customers about a certain brand (Hsieh et al., 2004). It can also be expressed through word of mouth communication whereby customers tend to share that past experience with others. Finally, brand leadership refers to ability to stand in a particular market with the presence of others and it can be reflected through brand popularity, quality, and innovations (Aaker, 1996).

\subsection{Product Innovation}

In today's business environment which is characterized by high competition, innovation has been widely accepted as one of the key sources in helping firms to build and maintain sustainable competitive advantages (Atalay et al., 2013; Fauji \& Utami, 2013). Certain scholars also viewed product innovation as one of the main strategic factors for organizational survival and success (Jimenez \& Sanz-Valle, 2011; Cho \& Pucik, 2005; Damanpour, 1996). Similarly, Gunday et al. (2011) considered innovativeness as one of the main strategies to drive organizational growth through entering new markets and to maximize the current market share. Advantages of product innovation include added values to both customers and the manufacturing brand, continuous advancement in organizational survival, rapid growth, efficient performance, and higher profitability (Atalay et al., 2013). For these reasons, it has become vital to note that innovation represents a primary goal for many organizations (Lipit, 2006).

Previous literature reported several views towards the conceptualization of product innovation. For instance, Atalay et al. (2013) referred product innovation to the ability of an organization to introduce different products or services that are new or significantly developed with reference to their features or intended purpose of usage. Likewise, Hoonsopon and Ruenron (2012) conceptualized product innovation as the creation of new products that have added values as compared with previous products to satisfy market needs. They further indicated that it is important for organizations to know about the expectations of their customers to make better decisions in terms of differentiation positioning tools. Johne (1999) described product innovation as the process of determining innovative unfulfilled customer needs and fixing new technologies in differentiated product attributes.

Forsman (2011) specified that innovation refers to the capability of an organization to successfully come up with new or improved products, which aim to enhance the overall competitiveness. Forsman (2011) further indicated that product innovattion was the main driver of firm performance and sustainability. In particular, product innovation approaches should help business managers improve the performance and operations of their organizations (Fauji \& Utami, 2013). This is because product innovations not only improve organizational growth, but also it is a tool to attain long-term sales effectiveness through various promotional activities. Thus, higher record of new products success can maximize sales volume and increases market share, which ultimately results in attracting new customers, at the same time maintaining the loyalty of old ones (Tu \& Hwang, 2013). 
The above discussion shows the importance of product innovation in helping firms to enhance their growth worldwide and strengthening their competitiveness. Particularly, the ability to generate new products and services that are meaningful to customers could result in higher performance and positive brand image (Sjöberg \& Wallgren, 2013). Innovative products include those which have differentiated features making it difficult for competitors to copy or imitate (Wilkinson \& Kannan, 2013). Therefore, being able to introduce new products with distinctive features which are functionally effective can support organizational success and lead to sustainable competitive advantage. For instance, focusing on interior product features such as technological aspects and coming up with attractive product designs with high quality may influence the perceptions of customers and improve their overall impression about the manufacturing brand. Such activities would ultimately influence consumer's decision making and brand evaluation. In this section, a discussion on the effect of product innovation on brand equity is presented below.

Product innovation is widely recognized as an important strategic factor for driving brand success, however, despite the importance of product innovations in helping firms to develop their brands, studies relating to its effect on brand equity are very limited (Ponnam, \& Balaji, 2015). Ghodeswar (2008) illustrated that firms can leverage their brand equity in a particular market through introducing new innovative products. Sinapuelas and Sisodiya (2010) also provided empirical evidence about the role of of product innovation in improving brand equity. Particularly, when a firm has the capability to associate product innovation with market orientation, it can gain strong brand equity (Gehani, 2001). Therefore, product innovation represents a vehicle to sustainable brand equity.

Previous studies confirmed that product innovation had a significant positive effect on brand equity (Beverland et al., 2007; Ponnam, \& Balaji, 2015; Sriram et al., 2007; Zou \& Fu, 2011). Beverland et al. (2007) revealed that brand leadership could be established through the introduction of innovative products as they can enhance brand reputation and strengthen brand position. Similarly, Hanaysha et al. (2014) found that product innovation had significant relationship with brand image. They indicated that product innovation helps firms secure strong brand image and obtains sustainable competitive advantage. Certain scholars also confirmed that product innovation significantly affected brand image (Shiau, 2014) and brand recognition (Hamid et al., 2012). Other studies (Naveed et al., 2012; Nemati et al., 2010) also found out product innovation was positively related to brand loyalty. Consequently, the following hypotheses are presented:

$\mathrm{H}_{1}$ : Product innovation has positive effect on brand awareness.

$\mathrm{H}_{2}$ : Product innovation has positive effect on brand loyalty.

$\mathrm{H}_{3}$ : Product innovation has positive effect on brand image.

$\mathrm{H}_{4}$ : Product innovation has positive effect on brand leadership.

$\mathrm{H}_{5}$ : Product innovation has positive effect on overall brand equity.

\section{Methodology}

The main purpose of this paper is to test the impact of product innovation on brand equity in automotive sector. The motive of this study refers to the belief that branding issues are very important for an organization's strategy formulation, and it is one of the driving tools for differentiating it from competitors in market environment that is highly challenging. Northern Malaysia has been chosen to conduct this study where a survey instrument was employed for collecting the data from passenger car owners at several shopping malls. To determine the appropriate sample size, this study referred to the table which was suggested by Krejcie and Morgan (1970). As the population exceeded one million in northern Malaysia, thus, a total of 384 passenger car users were chosen to participate in the survey voluntarily. To ensure the randomness of questionnaire distribution, systematic random sampling approach was followed whereby every $10^{\text {th }}$ customer who visited any of the selected shopping malls was requested to answer the survey. Data obtained from these questionnaires were analyzed through 
SPSS 19 and structural equation modeling on AMOS18. In particular, reliability and validity analyses were conducted to ensure the fitness of data for further analyses. Then, regression analysis based on structural model was conducted to examine the hypotheses.

To test the variables of this study, the measurement scale of each construct was adapted from past researches. As mentioned above, brand equity is composed of four dimensions namely brand loyalty, brand leadership, brand awareness, and brand image. Therefore, a 4-items scale of brand loyalty is adapted from Nigam and Kaushik (2011). Simialrly, brand leadership is measured through a 5-items scale taken from from the studies of Aaker (1996); and Liaogang et al. (2007). A 3-items scale of brand awareness is adapted from Yasin, Noor, and Mohamad (2007). To measure brand image, a 5-items scale is adapted from Nigam and Kaushik (2011), while the scale of product innovation is adapted with some modification from the study of Stock (2011). All of the measurement scales are tested using 7point Likert type.

\section{Analyses of Results}

Out of 384 questionnaires being distributed on the respondents, only 287 were returned back representing $74.7 \%$ of total response. The demographic profile revealed that $136(47.4 \%)$ of the respondents are male, whereas female accounted for 151 (52.6\%). On age profile, the results revealed that only 36 respondents were in the age category of 25 years or less, whereas the majority belong to the age category of 26-35 representing 140 (48.8\%). Those whose age between 36 and 45 recorded a total number of 46 , represented by $16 \%$. With regard to the last age group (46 years old and above), the study has 65 respondents, represented by 22.6\%. Furthermore, the findings indicated that 216 (75.3\%) of the respondents were Muslims, 42 (14.6\%) were Buddhists, 13 (4.4\%) were Hindu, 14 (4.9\%), were Christian, while 2 respondents $(0.7 \%)$ belong to other religions.

Additionally, confirmatory factor analysis was conducted to ensure construct and convergent validity. To do so, the factor loadings of each construct were calculated on AMOS through the measurement model. Specifically, factor loading of items with values exceeding 0.5 indicate the appropriateness of the measure as well as acceptable convergent validity. As illustrated in Table 1, the factor loadings of remaining items have achieved the minimum cut-off value of 0.5 (Hair et al., 2010), therefore, construct and convergent validity are supported. The reliability of measures was also calculated on all constructs using Cronbach's alpha through SPPS. The findings indicated that the reliability of all scales used in this study is acceptable, which exceeded the value of 0.70 (Hair et al., 2010). The details are shown in the below table.

To test the results of hypotheses which were developed on the variables of the study in literature review section (H1-H5), the regression analysis is used. Specifically, the results are extracted based on the outcomes of structural that is drawn on AMOS. This step was possible after ensuring that the structural model has achieved a good fit for the data using several indices. In general, the final structural model achieved a significant chi-square $(632.206, \mathrm{p}<0.05)$ taking into consideration the appropriate sample size used in this study. Other fit indices were also used to support chi-square and ensure the goodness of fit; $(\mathrm{GFI}=0.817$, TLI $=0.931$, CFI $=0.940$ and RMSEA $=0.079)$. These results indicate that the model achieved a reasonable fit for the data (Hair et al., 2010).

The findings presented in Table 2 show that product innovation has a significant positive effect on brand awareness $(\beta=0.397, \mathrm{CR}=6.13, \mathrm{p}<0.001)$ and explain the variance by $15.8 \%$, therefore, $\mathrm{H}_{1}$ is accepted. Similarly, it is also found that product innovation has a significant positive effect on brand loyalty $(\beta=0.744, \mathrm{CR}=11.867, \mathrm{p}<0.001)$, and explains $55.4 \%$ of its variance, hence, $\mathrm{H}_{2}$ accepted. In $\mathrm{H}_{3}$, it is proposed that product innovation has positive effect on brand image, therefore, the results presented in the below table support this hypothesis $(\beta=0.779, \mathrm{CR}=11.971, \mathrm{p}<0.001)$, and innovation explains the variance in brand image by $60.7 \%$. Furthermore, the findings revealed that product 
innovation has significant positive effect on brand leadership $(\beta=0.734$, CR $=11.856, \mathrm{p}<0.001)$ and explains 53.8 of its variance, thus, $\mathrm{H}_{4}$ is confirmed. Finally, the results indicated that product innovation has a significant positive effect on overall brand equity $(\beta=0.698, C R=6.554, p<0.001)$ and explains $48.7 \%$ of its variance, thus, $\mathrm{H}_{5}$ is supported.

Table 1

Factor Analysis Results and Cronbach’s Alpha Values

\begin{tabular}{|c|c|c|}
\hline Construct & Items & Loadings \\
\hline \multirow{7}{*}{$\begin{array}{l}\text { Product Innovation } \\
(\alpha=0.928)\end{array}$} & $\begin{array}{l}\text { PI1: This car brand is highly innovative compared to other car } \\
\text { brands in the market. }\end{array}$ & 0.815 \\
\hline & PI2: This car brand is frequently updated with new models. & 0.668 \\
\hline & $\begin{array}{l}\text { PI3: This car brand provides new alternatives for the } \\
\text { customers. }\end{array}$ & 0.858 \\
\hline & $\begin{array}{l}\text { PI4: This car brand is frequently supplemented with new } \\
\text { features and specifications for the customers }\end{array}$ & 0.856 \\
\hline & $\begin{array}{l}\text { PI5: This car brand differs from competing models in the } \\
\text { market. }\end{array}$ & 0.800 \\
\hline & $\begin{array}{l}\text { PI6: This car brand frequently comprises new features which } \\
\text { are meaningful to the customers. }\end{array}$ & 0.878 \\
\hline & $\begin{array}{l}\text { PI7: This car is considered to be innovative in terms of } \\
\text { product design. }\end{array}$ & 0.766 \\
\hline \multirow{3}{*}{$\begin{array}{l}\text { Brand Awareness } \\
(\alpha=0.941)\end{array}$} & BA1: I know how the symbol of this car brand looks like. & 0.900 \\
\hline & $\begin{array}{l}\text { BA2: I can recognize the brand of this car among other } \\
\text { competing brands. }\end{array}$ & 0.952 \\
\hline & BA3: I can quickly recall the symbol or logo of this car brand. & 0.902 \\
\hline \multirow{4}{*}{$\begin{array}{l}\text { Brand Loyalty } \\
(\alpha=0.914)\end{array}$} & BL1: I’m loyal to this car brand. & 0.858 \\
\hline & $\begin{array}{l}\text { BL2: If in future, I want to buy a new car this brand would be } \\
\text { my first choice. }\end{array}$ & 0.839 \\
\hline & BL3: I will recommend this car brand to my friends. & 0.930 \\
\hline & BL4: I will buy this car brand even if it increases the price. & 0.766 \\
\hline \multirow{5}{*}{$\begin{array}{l}\text { Brand Image } \\
(\alpha=0.934)\end{array}$} & BI1: This car brand has created a distinct image in my mind. & 0.806 \\
\hline & BI2: This car brand has given me whatever it promised to me. & 0.909 \\
\hline & BI3: This car brand provided me a better life style. & 0.906 \\
\hline & $\begin{array}{l}\text { BI4: This car brand I'm using is associated with the } \\
\text { manufacturer's image. }\end{array}$ & 0.851 \\
\hline & $\begin{array}{l}\text { BI5: The staff of this car brand is able to build strong brand } \\
\text { relationship with me }\end{array}$ & 0.828 \\
\hline \multirow{5}{*}{$\begin{array}{l}\text { Brand Leadership } \\
(\alpha=0.958)\end{array}$} & $\begin{array}{l}\text { BLe1: This car brand is one of the leading brands in its } \\
\text { category }\end{array}$ & 0.832 \\
\hline & BLe2: This car brand is growing in popularity. & 0.861 \\
\hline & $\begin{array}{l}\text { BLe3: This car brand is innovative, first with advances in } \\
\text { services. }\end{array}$ & 0.960 \\
\hline & $\begin{array}{l}\text { BLe4: This car brand is innovative, first with advances in } \\
\text { products }\end{array}$ & 0.953 \\
\hline & $\begin{array}{l}\text { BLe5: This car brand is stylish when it comes to product } \\
\text { design. }\end{array}$ & 0.919 \\
\hline
\end{tabular}


Table 2

Regression Analysis Results

\begin{tabular}{|c|c|c|c|c|c|}
\hline & Hypothesis & $\begin{array}{c}\text { Std. } \\
\text { Estimate }\end{array}$ & S.E & CR & $\mathrm{P}$ \\
\hline $\mathrm{H}_{1}$ : & $\begin{array}{l}\text { Product Innovation has Positive effect } \\
\text { on brand awareness }\end{array}$ & 0.397 & 0.065 & 6.13 & $* * *$ \\
\hline $\mathrm{H}_{2}$ : & $\begin{array}{l}\text { Product Innovation has Positive effect } \\
\text { on brand loyalty }\end{array}$ & 0.744 & 0.072 & 11.867 & $* * *$ \\
\hline $\mathrm{H}_{3}$ : & $\begin{array}{l}\text { Product Innovation has Positive effect } \\
\text { on brand image }\end{array}$ & 0.779 & 0.069 & 11.971 & $* * *$ \\
\hline $\mathrm{H}_{4}:$ & $\begin{array}{l}\text { Product Innovation has Positive effect } \\
\text { on brand leadership }\end{array}$ & 0.734 & 0.068 & 11.856 & $* * *$ \\
\hline $\mathrm{H}_{5}:$ & $\begin{array}{l}\text { Product Innovation has Positive effect } \\
\text { on overall brand equity }\end{array}$ & 0.698 & 0.048 & 6.554 & $* * *$ \\
\hline
\end{tabular}

\section{Discussion and Conclusion}

The rationale of this study was to examine the effect of product innovation on brand equity of automotive industry. The findings revealed that product innovation positively affected brand equity and its dimensions. Specifically, it is found that product innovation has a significant positive impact on brand awareness. In other words, the higher levels of innovation, the higher brand awareness will be. Sriram et al. (2007) demonstrated that when an organization introduces innovative products, it usually increases its advertising spending in order to build brand awareness and capture the attention of customers. Moreover, Hamid et al. (2012) confirmed that product innovation was positively related to brand recognition. This study also found that product innovation has significant positive impact on brand loyalty and it is in line with a number of previous research works (Akinyele, \& Ihinmoyan, 2010; Hussain, Munir, \& Siddiqui, 2012; Naveed et al., 2012). Shiau (2014) also found that technological innovation had significant positive impact on brand loyalty.

This paper also provides evidence that product innovation has significant and positive impact on brand image. The finding was supported by previous research (Hanaysha et al., 2014; Shiau, 2014). In particular, product Innovations can create new brand associations in consumers' memories which are unique to a brand and differentiate it from its competitors (Sinapuelas \& Sisodiya, 2010). Similarly, the findings of this study indicated that product innovation has significant positive impact on brand leadership. This means that being capable to come up with innovative products will ease the process of gaining leadership position in certain target market. For example, automotive brands such as Toyota, Honda, and BMW have successfully managed to launch new products with attractive product designs and high quality of interior features. Their capabilities to come up with such offers have differentiated them from competitors and enabled them to become among the leading automotive brands. Therefore, to become highly competitive, car manufacturers should focus on introducing attractive product designs with creative interior features based on high technology. With such activities, firms can gain sustainable competitive advantage and obtain higher market shares.

Finally, this study found that product innovation has significant positive impact on overall brand equity. The result is in line with previous researches which reported that product innovation was positively related to brand equity (Ponnam \& Balaji, 2015; Sriram et al., 2007; Zou \& Fu, 2011). This means that introducing new products with innovative features can help organizations to enhance their brand equity and ensure their sustainable development. Bverland et al. (2010) illustrated that successful product innovations can reinforce brand equity and improve brand value as well as long-term profitability. Similarly, Beverland et al. (2010) considered product innovation as an important factor for driving 
brand equity. Therefore, product innovation plays an important role in increasing the attractiveness of products, improve the value proposition to customers, and develop brand loyalty among existing customers to sustain their values on the long-term (Aaker, 2007). This as a result will lead to sustainable brand equity and better performance.

This study has several limitations that should be addressed in future researches. First, it has focused only on one antecedent of brand equity that is product innovation. Therefore, future research is recommended to test other factors to verify their effects on brand equity. Second, this study was conducted among passenger car owners in northern region of Malaysia. Past studies have paid less attention to examining the antecedents of brand equity in Asian context, thus, future research is recommended to test the antecedents of brand equity in Asian contexts including different sectors. Additionally, brand leadership has been considered as an important dimension of brand equity, but only few studies contributed to its measurement as a component of brand equity. Future research should look into this opportunity. Moreover, this study relied only on customers to test the hypotheses; hence, future research can also consider managers to obtain better insights on how to build sustainable brand equity. Finally, this study used questionnaire instrument to collect the data from respondents, therefore, future research may employ different methodologies and use longitudinal data.

In conclusion, this study suggests that automotive manufacturers should pay significant attention to the importance of product innovation in building sustainable brand equity. Generally, it reveals that when an organization has the capability to introduce innovative products that are difficult for competitors to imitate or copy, it can win customers' preferences and enhance their purchase decisions. The findings also suggests that automotive manufacturers should emphasize on production quality, enhancing interior and exterior product attributes, and ensure product customization in response to consumer and market needs. In fact, customers will develop brand loyalty and positive word of mouth according to their past experiences on account of good quality products that are also innovative and fulfill their expectations. Particularly, as cusumers' needs and expectations are continuously changing, it has become necessary to meet those needs and ensure their commitment to the brand. By doing so, firms will be able to respond to intense competition and face challenging market environments.

\section{References}

Aaker, D. A. (1991). Managing brand equity. New York: The Free Press.

Aaker, D. A. (1996). Measuring Brand Equity Across Products and Markets. California Management Review, 38(3), 102-20.

Aaker, D. A. (2007). Innovation: Brand it or lose it. California Management Review, 50(1), 8-24.

Aaker, D. A., \& Keller, K. L. (1990). Consumer evaluations of brand extensions. Journal of Marketing, 54, 27-41.

Ailawadi, K. L., Lehmann, D. R., \& Neslin, S. A. (2003). Revenue premium as an outcome measure of brand equity. Journal of Marketing, 67(4), 1-17.

Akinyele, S. T., \& Ihinmoyan, T. (2010). Effect of innovation on brand loyalty and customer satisfaction: A study of mobile phones users in Ota-Nigeria. Journal of Management Research, 2(3), 78-90.

Atalay, M., Anafarta, N., \& Sarvan, F. (2013). The relationship between innovation and firm performance: An empirical evidence from Turkish automotive supplier industry. Procedia-Social and Behavioral Sciences, 75, 226-235.

Beverland, M. B., Napoli, J., \& Farrelly, F. (2010). Can all brands innovate in the same way? A typology of brand position and innovation effort. Journal of Product Innovation Management, 27(1), 33-48.

Beverland, M., Napoli, J., \& Lindgreen, A. (2007). Industrial global brand leadership: A capabilities view. Industrial Marketing Management, 36(8), 1082-1093. 
Broniarczyk, S. M., \& Alba, J. W. (1994). The importance of the brand in brand extension. Journal of Marketing Research, 31, 214-228.

Buil, I., de Chernatony, L., \& Martínez, E. (2008). A cross-national validation of the consumer-based brand equity scale. Journal of Product \& Brand Management, 17(6), 384-392.

Cho, H., \& Pucik, V. (2005). Relationship between innovativeness, quality, growth, profitability, and market value. Strategic Management Journal, 26(6), 555-570.

Damanpour, F. (1996). Organizational complexity and innovation: developing and testing multiple contingency models. Management Science, 42(5), 693-716.

Farquhar, P. (1989). Managing brand equity. Marketing Research,1, 24-33.

Fauji \& Utami, M. M. (2013). How Intellectual Stimulation Effects Knowledge Sharing, Innovation and Firm Performance. International Journal of Social Science and Humanity, 3(4), 420-425.

Forsman, H. (2011). Innovation capacity and innovation development in small enterprises. A comparison between the manufacturing and service sectors. Research Policy, 40(5), 739-750.

Gehani, R. R. (2001). Enhancing brand equity and reputational capital with enterprise-wide complementary innovations. Marketing Management Journal, 11(1), 35-48

Ghodeswar, B. M. (2008). Building brand identity in competitive markets: a conceptual model. Journal of Product \& Brand Management, 17(1), 4-12.

Gunday, G., Ulusoy, G., Kilic, K., \& Alpkan, L. (2011). Effects of innovation types on firm performance. International Journal of Production Economics, 133(2), 662-676.

Gupta, S., Lehmann, D. R., \& Stuart, J. A. (2004). Valuing customers. Journal of Marketing Research, 41, 7-18.

Hair, J. F., Jr., Black, W. C., Babin, B. J., Anderson, R. E., \& Tatham, R. L. (2010). Multivariate data analyisis (7th ed.) NJ: Pearson Prentice Hall.

Hamid, M., Rasool, S., Kiyani, A. A., \& Ali, F. (2012). Factors affecting the brand recognition; An exploratory study. Global Journal of Management \& Business Research, 12(7), 75-82.

Han, J.K. , Kim, N., \& Kim, H. (2001). Entry barriers: a dull-, one-, or two-edged sword for incumbents? Unraveling the paradox from a contingency perspective. Journal of Marketing, 65(1), $1-14$.

Hanaysha, J., Hilman, H., Abd. Ghani, N. H. (2013). Assessing the literature on brand equity: From past, present to future. Australian Journal of Basic \& Applied Sciences, 7(14), 488-499.

Hanaysha, J., Hilman, H., \& Abdul-Ghani, N. H. (2014). Direct and indirect effects of product innovation and product quality on brand image: Empirical evidence from automotive industry. International Journal of Scientific and Research Publications, 4(11), 1-7

Hoonsonpon, D., \& Ruenrom, G. (2012). The impact of organizational capabilities on the development of radical and incremental product innovation and product innovation performance. Journal of Managerial Issues, 24(3), 250-276

Hsieh, M. H., Pan, S. L., \& Setiono, R. (2004). Product-, corporate-, and country-image dimensions and purchase behavior: A multicountry analysis. Journal of the Academy of Marketing Science, 32(3), 251-270.

Hussain, M., Munir, A., \& Siddiqui, M. (2012). Impact of innovation in FMCG products on customer loyalty and satisfaction: A case study of Confectionary Producer "English Biscuit Manufacturers" in Pakistan. Interdisciplinary Journal of Contemporary Research in Business, 4(8), 423-431.

Jimenez, J. D., \& Sanz-Valle, R. (2011). Innovation, organizational learning and performance. Journal of Business Research, 64(4), 408-417.

Johne, A. (1999). Successful market innovation. European Journal of Innovation Management, 2(1), 6-11

Keller, K. L. (1993). Conceptualizing, measuring, and managing customer-based brand equity. Journal of Marketing, 57, 1-22.

Krejcie, R. V., \& Morgan, D. W. (1970). Determining sample size for research activities. Educational and Psychological Measurement, 30, 607-610.

Lassar, W., Mittal, B., \& Sharma, A. (1995). Measuring customer-based brand equity. Journal of consumer marketing, 12(4), 11-19. 
Lieven, T., Grohmann, B., Herrmann, A., Landwehr, J. R., \& Tilburg, M. (2014). The effect of brand gender on brand equity. Psychology \& Marketing, 31(5), 371-385.

Lipit, M. (2006). Patterns in innovation: Goals and organization life cycle. Human Resource Planning Society Journal, 73-77.

Mela, C. F., Gupta, S., \& Lehmann, D. R. (1997). The long-term impact of promotion and advertising on consumer brand choice. Journal of Marketing Research, 34, 248-261.

Naveed, T., Akhtar, I., \& Cheema, K. U. R. (2012). The impact of innovation on customer satisfaction and brand loyalty: A study of the students of Faisalabad. International Journal of Management \& Organizational Studies, 2(2), 62-68.

Nemati, A. R., Khan, K., \& Iftikhar, M. (2010). Impact of innovation on customer satisfaction and brand loyalty, a study of mobile phones users in Pakistan. European Journal of Social Sciences, 16(2), 299-306.

Nigam, A., \& Kaushik, R. (2011). Impact of brand equity on customer purchase decisions: An empirical investigation with special reference to hatchback car owners in central Haryana. International Journal of Computational Engineering \& Management, 12, 121-128.

Park, C. S., \& Srinivasan, V. S. (1994). A survey-based method for measuring and understanding brand equity and its extendibility. Journal of Marketing Research, 31, 271-288.

Ponnam, A., \& Balaji, M. S. (2015). Investigating the effects of product innovation and ingredient branding strategies on brand equity of food products. British Food Journal, 117(2), 523-537.

Pouromid, B., \& Iranzadeh, S. (2012). The evaluation of the factors effects on the brand equity of Pars Khazar household appliances based on the vision of female consumers. Middle-East Journal of Scientific Research, 12(8), 1050-1055.

Nemati, A. R., Khan, K., \& Iftikhar, M. (2010). Impact of innovation on customer satisfaction and brand loyalty, a study of mobile phones users in Pakistan. European Journal of Social Sciences, 16(2), 299-306.

Shiau, H. C. (2014). The impact of product innovation on behavior intention: The measurement of the mediating effect of the brand image of Japanese Anime Dolls. Anthropologist, 17(3), 777-788.

Sinapuelas, I. C., \& Sisodiya, S. R. (2010). Do line extensions influence parent brand equity? An investigation of supermarket packaged goods. Journal of Product and Brand Management, 19(1), 18-26.

Sjöberg, A., \& Wallgren, C. (2013). Product innovation and the effects of CRM usage: A quantitative study. Master Thesis, School of Business \& Economics, Linnaeus University.

Sriram, S., Balachander, S., \& Kalwani, M. U. (2007). Monitoring the dynamics of brand equity using store-level data. Journal of Marketing, 71(2), 61-78.

Tu, C., \& Hwang, S. N. (2013). Innovation and success in micro-enterprises: The role of family and environments. International Proceedings of Economics Development \& Research, 70.

Wilkinson, T. J., \& Kannan, V. R. (2013). Strategic Management in the 21st Century. California: ABCCLIO.

Yang, J., Zhang, M., \& Zou, Z. (2015). The effect of In-Game advertising in SNS on brand equity. Journal of Service Science and Management, 8(01), 107-114.

Yasin, N. M., Noor, M. N., \& Mohamad, O. (2007). Does image of country-of-origin matter to brand equity? Journal of Product \& Brand Management, 16(1), 38-48.

Zou, S., \& Fu, H. (2011). International Marketing: Emerging Markets: Emerging Markets (Vol. 21). Emerald Group Publishing. 